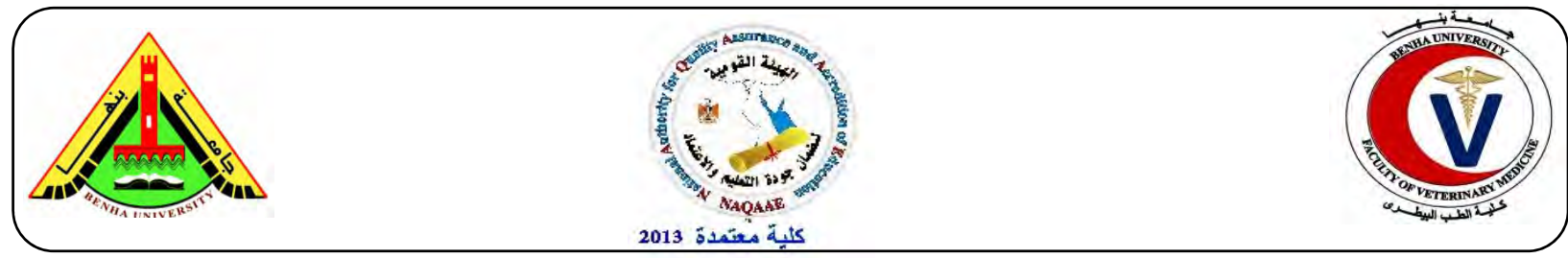

\title{
Hepatoprotective effect of asparagus racemosus in paracetamol induced hepatotoxicity in rats.
}

\author{
Yakout A. El-Senosiy'; Souad A. Ahmad ${ }^{2}$; Ayman S. Farid ${ }^{3}$; Wessam E.M. \\ ${ }^{1}$ Department of Biochemistry, Fac. of Vet. Med., Benha Univ., Egypt. \\ ${ }^{2}$ Department of Hygiene, Behavior and Management of animal, Fac. of Vet. Med., Benha Univ., Egypt. \\ ${ }^{3}$ Department of Clinical Pathology, Fac. of Vet. Med., Benha Univ., Egypt.
}

\section{A B S T R A C T}

The Asparagus racemosus was evaluated for its hepatoprotective activities against paracetamol induced hepatotoxicity in rats. Forty rats were used divided into 2 groups, normal control: Composed from 10 rats and Hepatotoxicity induced group composed from 30 rats administrated of paracetamol by dose $1 \mathrm{gm} / \mathrm{kg} \mathrm{b}$. wt. orally. For 10 days, then every $72 \mathrm{~h}$. Until the end of experiment time. This group subdivided into 3 subgroup: 1-Paracetamol group: 10 rats as control negative. 2-Silymarin treated group: 10 rats taken silymarin by dose $100 \mathrm{mg} / \mathrm{kg}$ daily P.O. for (15) days (Kumar et al., 2011)._3-Asparagus treated group: 10 rats administrated Asparagus racemosus powder by dose $500 \mathrm{mg} / \mathrm{kg} \mathrm{b}$. Wt. daily P.O. for 15 days. (Kumar et al., 2011 and Sara et al., 2013). Paracetamol-induced a significant increase in, aspartate amino transferase (AST), alanine amino transferase (ALT), alkaline phosphatase (ALP), with marked reduction in superoxide dismutase (SOD) and catalase (CAT) activities. Treatment of rats with Asparagus racemosus (500 mg/kg b. wt.) significantly altered serum marker enzymes and antioxidant status to near a normal level against paracetamol-treated rats. Such hepatoprotective activities of Asparagus racemosus were comparable to silymarin administrated ( $100 \mathrm{mg} / \mathrm{kg} \mathrm{b}$. wt. p.o.). The results indicate that the hepatoprotective properties of Asparagus racemosus against paracetamol-induced hepatotoxicity in rats

Keywords: Paracetamol, Asparagus racemosus, hepatotoxicity, antioxidants.

(http://www.bvmj.bu.edu.eg)

(BVMJ-28(1): 133-137, 2015)

\section{INTRODUCTION}

The liver is the key organ regulating homeostasis in the body. It is involved with almost all the biochemical pathways related to growth, fight against disease, nutrient supply, energy provision and reproduction (Ward et al., 1999). Also the liver is expected not only to perform physiological functions but also to protect against the hazards of harmful drugs and chemicals (Pang et al., 1992). Liver protective herbal drugs contain a variety of chemical constituents like phenols, coumarins, lignans, essential oils, monoterpenes, carotinoids, glycosides, flavonoids, organic acids, lipids, alkaloids and xanthines. (Sharma et al., 2002).
Asparagus racemosus (Liliaceae) is a popular vegetable consumed in many parts of the world and grows naturally throughout India, Asia, Australia and Africa. It is commonly used for the treatment of diarrhea, dysentery, rheumatism, nervous breakdown, and is thought to be an aphrodisiac (Nadkarni, 1976). Studies on the extracts of Asparagus racemosus have revealed a wide range of biological activities. These include antimutagenic, anti-tumor, antifungal (Edenharder, 1990 and Shimoyamada et al., 1990), diuretic (Balansard and Rayband, 1987), antiulcer activity (Singh, K,P and Singh, R.H. 1986) and 
immunostimulatory effects (Thatte, and Dahanukar, 1988). However Asparagus racemosus has been considered to be a lactogogue in lactational inadequacy (Sharma et al., 1996), and useful to decrease postoperative adhesions and it also have anticandidal activity (Uma et al., 2009). Aim of work is determination of the serum concentration of: Alanine amino transferase (ALT) - Aspartate amino transferase (AST) - Alkaline phosphatase (ALP) at15 days of Asparagus and silymarin administration. Also determination of hepatic oxidative stress parameters: Catalase (CAT) and Super oxide dismutase (SOD).

\section{MATERIAL AND METHODS}

\subsection{Experimental animals:}

A total number of 40 male albino rats, weighting 170-200 $\mathrm{g}$ were used in the experimental investigation of this study. Rats were obtained from the laboratory animal's research center, faculty of veterinary medicine, Benha University. Animals were housed in separate cages, fresh and clean water was supplied adlibtium. Rats were kept at a constant environmental and nutritional condition throughout the period of the experiment. Animals were left for 10 days for adaptation period before the beginning of the experiment.

\subsection{Natural products:}

Asparagus racemosus powder was obtained from Harraz shop, Cairo, Egypt.

\subsection{Drugs and dosage:}

2.3.1. Silymarin sachet (140mg powder) dissolved in water and administrated by dose $100 \mathrm{mg} / \mathrm{kg} \mathrm{b}$. wt orally. Manufacture by European Egyptian Pharm. Alexandria Egypt.

2.3.2. Paracetamol was provided from Misr Pharmaceutical Company, Cairo, Egypt. Each $5 \mathrm{ml}$ syrup contains $120 \mathrm{mg}$ of paracetamol.

\subsubsection{Experimental design:}

At the beginning of the experiment, rats were divided into 2 groups

Group: - normal control: Composed from 10 rats were fed normal diet.

Group 2:- Hepatotoxicity induced group composed from 30 rats were fed normal diet and administration of paracetamol by dose $1 \mathrm{gm} / \mathrm{kg} \mathrm{b}$. wt. orally. For 10 days, then every $72 \mathrm{~h}$. Until the end of experiment time 15 days. This group subdivided into 3 subgroup:

1-Paracetamol group: 10 rats as control negative.

2-Silymarin treated group: 10 rats taken silymarin by dose $100 \mathrm{mg} / \mathrm{kg}$ daily P.O. for (15) days. (Kumar et al., 2011)

3-Asparagus treated group: 10 rats administrated Asparagus racemosus powder by dose $500 \mathrm{mg} / \mathrm{kg} \mathrm{b}$. Wt. daily P.O. for 15 days. (Kumar et al., 2011 and Sara et al., 2013)

\subsection{4 .Sampling:}

Blood samples were collected from all animals 15 day from onset of treatment with Asparagus racemosus and silymarin. The samples were allowed to coagulate and then centrifuged at $3000 \mathrm{rpm}$ for $5 \mathrm{~min}$; the serum separated was used for determination of liver marker enzymes ALT, AST, and ALP activities. The liver samples were collected after the end of experiment. Immediately after killing the animals by decapitation, the liver was removed by dissection, washed with ice-cold isotonic saline and blotted between 2 filter papers. Then the liver part $1.0 \mathrm{gm}$ liver tissue was homogenized in $10 \mathrm{ml}$ of $50 \mathrm{mM}$ potacium Phosphate buffer centrifuged at $4000 \mathrm{rpm}$ and $4{ }^{\circ}$ for $10 \mathrm{~min}$ the aqueous upper layer was collected and kept at $0-4{ }^{\circ} \mathrm{C}$ for immediate assay of: Hepatic Super oxide dismutase (SOD, and Hepatic Catalase (CAT) activities.

\subsubsection{Biochemical Analysis:}


Serum ALT, AST, and ALP were determined according to the method of (Young. 2001). Moreover, the supernatant of hepatic tissue homogenate were used for the determination of catalase and superoxide dismutase was estimated according to the methods of (Sinha, 1972) and (Kakkar, et al., 1984) respectively.

\subsubsection{Statically Analysis:}

Results data were analyzed using SPSS (Statistical package for social science; ver. 10.0) and the significance among the samples was compared at $\mathrm{P}>0.05$. Results were represented as mean $\pm \mathrm{SD}$.

\section{RESULTS}

3.1. Effect of paracetamol, Asparagus racemosus and silymarin on liver marker enzymes in serum of rats:

The obtained data in table (1) revealed that administration of $1 \mathrm{gm} / \mathrm{kg} \quad$ b.Wt. of paracetamol significantly increased (ALT, AST and ALP) activities when compared to control group. However the treated with administration of Asparagus racemosus and silymarin significantly decreased serum enzymatic activity of (ALT, AST and ALP) when compared to hepatotoxicity induced group.

\subsection{Effect of paracetamol, Asparagus} racemosus and silymarin in liver SOD and CAT activities in rats:

The data represented in the table (1) revealed that paracetamol administered at dose (1gm/kg b.wt) significantly decreased hepatic SOD, catalase (CAT) activities when compared to control group. However administration of Asparagus racemosus at dose $500 \mathrm{mg} / \mathrm{kg}$ b.wt and silymarin at dose( $100 \mathrm{mg} / \mathrm{kg} \mathrm{b.wt)} \mathrm{marked} \mathrm{increased} \mathrm{hepatic}$ SOD, and catalase (CAT) activities as compared to and paracetamol administrated group.

\section{DISCUSSION}

The obtained data demonstrated in table (1) revealed that the administration of Asparagus Racemosus to hepatotoxicity induced rats decrease the serum ALT, AST, and ALP activities when compared with paracetamol treated group. In liver damage by paracetamol, the determination of enzyme activities such as ALT, AST is largely used. In the present study, the increase in serum activities of ALT, AST, and ALP activities in paracetamol treated rats had been contributed to the damaged structural integrity of the liver, because these are normally located in the cytoplasm, mitochondria or microsome and released into the circulation after cellular damage (Sallie and Tredger, 1991) or due to alterations in the permeability of cell membrane and increased synthesis or decreased catabolism of aminotransferases (Nuduka, 1999). On the other hand, (Rahiman et al., 2011) reported that, the reduction of AST and ALT activities by the Asparagus racemosus extracts is an indication of repair of hepatic tissue damage induced by paracetamol. The aqueous extract induced suppression of increased ALT and AST activities. Thus, administration of Asparagus racemosus revealed hepatoprotective activity against the toxic effect of paracetamol. These results showed improvement in activities of ALT, AST, and ALP enzymes was recorded in Asparagus racemosus group that due to its antioxidant effect. The obtained results showed in the table (1) revealed that paracetamol at dose $1 \mathrm{~g} / \mathrm{kg} \quad \mathrm{b}$. wt significantly decreased hepatic catalase, and superoxide dismutase when compared with control group. Similarly (Kuvandik et al., 2008) who reported that the activities of SOD, and CAT in liver tissue were decreased in the paracetamol group. Also, (Farghaly and Hussein, 2010) reported that, paracetamol induced hepatotoxicity in rats resulted in decreased level of hepatic (CAT) activity as compared to control rats. However (Weydert et al., 2006) found that, 
Table (1) The effect of Asparagus racemosus and silymarin on serum ALT, AST, and ALP, hepatic SOD, and CAT in paracetamol induced hepatotoxicity in rats after (15) days:

\begin{tabular}{|c|c|c|c|c|c|}
\hline & ALT & AST & ALP & SOD & $\overline{\mathrm{CAT}}$ \\
\hline Control & $38.23 \pm 2.47^{\mathrm{bc}}$ & $\begin{array}{c}119.70 \pm 19.67 \\
\text { ab }\end{array}$ & $\begin{array}{c}163.85 \pm 16 . \\
81^{\mathrm{b}}\end{array}$ & $51.92 \pm 5.30^{\mathrm{a}}$ & $29.50 \pm .94^{\mathrm{a}}$ \\
\hline Paracetamol & $78.90 \pm 3.45^{\mathrm{a}}$ & $\begin{array}{c}151.93 \pm 25.84 \\
\mathrm{a}\end{array}$ & $\begin{array}{c}261.03 \pm 32 . \\
47^{\mathrm{a}}\end{array}$ & $\begin{array}{c}26.614 \pm 2.4 \\
5^{\mathrm{c}}\end{array}$ & $\begin{array}{c}13.10 \pm 3.2 \\
6^{\mathrm{b}}\end{array}$ \\
\hline $\begin{array}{l}\text { Asparagus } \\
\text { racemosus }\end{array}$ & $46.19 \pm 3.23^{b}$ & $99.93 \pm 10.07^{b}$ & $\begin{array}{c}153.94 \pm 18 . \\
97^{\mathrm{b}}\end{array}$ & $\begin{array}{c}35.61 \pm 4.84^{b} \\
c\end{array}$ & $\begin{array}{c}19.21 \pm 3.1 \\
5^{b}\end{array}$ \\
\hline Silymarin & $20.30 \pm 7.96^{\mathrm{c}}$ & $97.37 \pm 5.57^{\mathrm{b}}$ & $\begin{array}{c}143.71 \pm 22 . \\
24^{\mathrm{b}}\end{array}$ & $\begin{array}{c}44.98 \pm 4.76^{\mathrm{a}} \\
\mathrm{b}\end{array}$ & $\begin{array}{c}20.82 \pm 2.1 \\
6^{\mathrm{b}}\end{array}$ \\
\hline
\end{tabular}

Data was expressed as mean \pm SE. SE $=$ standard error. The mean values with different super script letter within the same column were significantly differing at $P>0.05$.

during cell membrane damage, various enzymes leak down to the circulatory fluid and their assessment in serum serves as markers in clinical studies. SOD is the first antioxidant enzyme to deal with oxyradicals by accelerating the dismutation of superoxide to hydrogen peroxide, while CAT is a peroxisomal haem protein that catalyzes the removal of hydrogen peroxide formed during the reaction catalyzed by SOD. Thus, SOD and CAT act as antioxidative enzymes, which provide protective defense against reactive oxygen species. This suggestion was confirmed by the founding of (Rahiman et al., 2011) who said that, SOD and CAT activities were decreased in paracetamol treated animal, which may be due to altered antioxidant status. This is in accordance with results that indicated a decreased CAT in paracetamol injected animals may be due to the utilization of antioxidant enzymes in the removal of released $\mathrm{H} 202$ released, SOD and CAT activities increased significantly in the treated group versus the untreated animals. From the obtain Results indicate the hepatoprotective properties of Asparagus and silymarin against paracetamol-induced hepatotoxicity in rats.

\section{Acknowledgment:}

Special thanks for center excellence in scientific research (CESR), faculty of veterinary medicine that funded by management supporting excellence (MSE) and Benha University

\section{REFERENCES}

Balansard, S., Rayband, M. 1987. Diuretic action of Asparagus racemosus. Critical Reviews in Society of Biology. 126: 954-956.

Edenharder, R. 1990. Anti-mutagenic activity of vegetable and fruit extracts against invitro benzo(a)pyrene. Zeitschrift fur Gesamte. Hygiene. 36: 144-148.

Farghaty, H.S. Hussein, M.A. 2010. Protective effect of Curcumin against paracetamol induced liver damage. Aust. J. OF Basic and Appl. sci.

Kakkal, P., Das, B., Viswanathan, P.N. 1984. A modified spectrophotometric assay of superoxide dismutase. Indian J. Biochem. Biophys.21:130132.

Kaplan, A. 1984. Clin Chem The C.V. Mosby Co.

Kumar, R.M., Fasalu, R., Tamizahm, T., kumar, B., Phaneendra, Surendra, B., 2011: Evaluation of hepatoprotective activity of asparagus racemosus root against paracetamol induced acute liver injury in rats Pharmacology on 
line Ind. J. of Novel Drug Dlivery 1:1059-1066.

Kuvandik, G., Duru, M., Nacar, Y.Z., Helvaci, R. Sogut, S. 2008. Effects of Erdosteine on acetaminophen induced hepatotoxicity in rats. Toxico. Patho., 36: 714-719.

Nadkarni, A.K. 1976. India Materia Medica, Bombay: Popular Prakashan; 151-155.

Nuduka, N. 1999. Clinical biochemistry for students of pathology, Longman Nigerian Pic.1-236.

Pang, S., Xin, X., Stpierre, M.V. 1992. Determinants of metabolic disposition. Ann Rev Pharmacol Toxicol. 1992; 32: 625-626.

Rahiman, F., Rupesh Kumar, O.M., Ttamizh Mani, M., Mohamed, N. T., Satya, Kumar, B., Phaneendra, P. Surendra, B. 2011. Hepatoprotective activity of "Asparagus Racemosus Root" on liver damage caused by Paracetamol in rats. Ind. J. of Novel Drug delivery. 3(2), 112-117.

Salli, R., Tredger, J. 1991. Drugs and the liver. Biopharmaceut and Disposition.12:251-259.

Sara, V.C., Rocío, D.P., María, G.G., María, A.F., Rafael, G.B. 2013. Bioactive constituents from "Triguero" Asparagus improve the Plasma Lipid profile and liver antioxidant status in hypercholesterolemic rats. Int. J. Mol. Sci. 14 :21227-21239.

Sharma, S., Ramji, S., Kumari, S., Bapna, J.S. 1996. Randomized control trial of A. system in islets of Langerhans and its role in the control of insulin release. Indian Pediatrics. 32: 675677.
Sharma, S.K., Ali, M., Gupta, J. 2002. Hepatoprotective activity of aqueous ethanolic extract of chamomile capitula in paracetamol intoxicated albino rats Phytochemist. and Pharmaco., 57: 253-270.

Shimoyamada, M., Suzuki, M., Sonta, H., Maruyama, M., Okubo, K.1990. Antifungal activity of the saponin fraction obtained from asparagus and its active principle. Agricult. and Biolo. Chem. 54: 2553-2557.

Sinha, A. 1972. Colorimetric assay of catalese. Anal. Biochem, 47:389.

Singh, K.P., Singh, R.H. 1986.Clinical trial on Satavari (Asparagus racemosus Wild.) in duodenal ulcer disease. J. Res. Ay. Sid. 7:91-100.

Thatte, U.M., Dahanukar, S.A. 1988. Comparative study of immunomodulating activity of Indian medicinal plants, lithium carbonate and glucan. Methods and Findings in Experimental and Clinical Pharmacology. 10: 639-644.

Uma, B., Prabhakar, K., Rajendran, S. 2009. Anticandidal activity of Asparagus racemosus. Ind. J. of Pharma. Sci. 71(3): 64-71.

Ward, F.M., Daly, M.J. 1999. Hepatic disease. In Clinical Pharmacy and Therapeutics. Walker R, Edward C, Eds, Churchill Livingston, New York, 195-212.

Weydert, C.J., Waugh, T.A., Ritchie, J.M., Iyer, K.S., Smith, J.L., Spitz, Oberle, L.W. 2006. Over expression of manganese or copper-zinc superoxide dismutase inhibits breast cancer growth. Free Rad. Biol. Med. 41: 226237.

Yong, D.S.2001. Effects of disease on Clinical Lab Tests, 4th, Ed AACC. 